\author{
Kamil Kowalski \\ University of Lodz \\ Faculty of Economics and Sociology \\ Department of History of Economic Thought and Economic History \\ e-mail: kamil.kowalski@uni.lodz.pl
}

\title{
Remarks on the genesis of UNRRA Negotiations between the Great Powers and selected treaty provisions
}

\begin{abstract}
As a conceptual framework, UNRRA referred to one of the four freedoms (freedom from want) mentioned by Franklin D. Roosevelt in a speech given in Congress on January 6,1946 . In the first section, the article presents early attempts to coordinate assistance for the civilian population during World War II (The Committee of Supplies and The Inter-Allied Committee on European Post-War Requirements). The scale of actions taken was very small and insufficient. In January 1942, the USSR proposed the creation of an international organization that would collect information on raw materials and food. This initiative prompted Washington and London to launch a separate competitive project. The organization's task was to bring help until the state gained economic independence. Therefore, the organization's goal was not to rebuild the areas affected by war damage in the long term (rehabilitation not reconstruction). In the main part, the article presents the basic issues in dispute when creating the principle of allocating aid, for example, the requirement of consent of the receiving state to receive gifts or the composition of organs of the organization. For this purpose, the exchange of notes between Washington and London was analyzed. Differences of opinions delayed the signing of the contract which did not take place until November 1943.
\end{abstract}

Keywords: UNRRA, Roosevelt, economic aid, hunger

JEL Classification: N42, N44 


\section{Introduction}

The signatories of the Atlantic Charter, ${ }^{1}$ in the sixth point of the document, expressed the hope that in the postwar world people would live free from fear and want. ${ }^{2}$ The charter contained a list of idealistic principles to which the signatory states would aspire. These goals were, among others, common disarmament, selfdetermination of nations, and resignation from the forceful resolution of international disputes. The catalog of countries' desirable behaviors contained ambitious goals requiring cooperation. Above all, it was a solution that required time. The most urgent postulate was the issue of reducing want. During the Second World War, millions of people experienced it.

110 million soldiers (during the Great War 70 million) from 61 countries took part in the war, while war activities were carried out in 40 countries. Its scope reached 1.7 billion people, i.e., $80 \%$ of the world's population. The want was the result of the destruction, which affected, in particular, the occupied parts of the USSR-70\% of industrial equipment and $60 \%$ of modes of transport were destroyed in these areas. ${ }^{3}$ Yugoslavia lost $40 \%$ of its industrial plants, Hungary-24\% (Kaliński, 2004, p. 222). Modern technology, most often the ally of man, in the face of hostilities proved to be a source of destruction and general conflagration on the battlefield. The situation of the civilian population considerably worsened. Unlike during previous armed conflicts, this war had dramatic effects on non-military ones. As noted by N. Davies:

for every European citizen fighting on the fronts of World War II, there were at least ten civilians who were not directly involved in the war but had to bear the painful consequences of the international conflict. (2008, p. 365)

Their experience, apart from the tragic events, when these people were losing their lives, were resettled or deported to labor camps, was poverty and hunger. The deterioration of the food situation in some European countries is illustrated in the table below.

\footnotetext{
${ }^{1}$ The Atlantic Charter was drafted by Franklin D. Roosevelt and Winston Churchill on the ship "Prince of Wales" off the coast of Newfoundland on August 14, 1941. It was an eight-point declaration, containing a set of rules of international coexistence, which were to apply to the signatories of the document (from September 1941, among others, the USSR, Poland, Czechoslovakia, Belgium) during and after the war. Card text in Rozbicki \& Michałek, 1994, pp. 371-372.

2 During his speech in Congress on January 6, 1941, Roosevelt listed four freedoms for which democratic states fight: freedom of speech, freedom of worship, freedom from want and freedom from fear. He stressed that America should support countries fighting with Axis states by transferring arms. For this purpose, the Lend-Lease Act was adopted in March. It authorized the US president to donate $\$ 7$ billion to military aid for the Allies. In addition to armaments, modes of transport, food, machinery and clothing were provided. More information about deliveries to the USSR as part of the Lend-Lease program, including specific areas of assistance (cf. Davies, 2008, p. 55).

${ }^{3}$ On the other hand, only $6 \%$ of the territory of the USSR was subject to German occupation in the era of the greatest successes of the army of the Third Reich. Cf. Davies, 2008, p. 371.
} 
Table 1. The level of consumption in calories per person per day in selected European countries in the years 1935-1938 and 1943-1944

\begin{tabular}{lcc} 
& 1935-1938 & 1943-1944 \\
\hline Austria & 2933 & 2440 \\
\hline Czechoslovakia & 2761 & 2228 \\
\hline Greece & 2523 & 1550 \\
\hline Italy & 2627 & no data \\
\hline Poland & 2702 & no data \\
\hline Yugoslavia & 2866 & 2351
\end{tabular}

Note: Adapted from "Introduction: Relief in the aftermath of war," by J. Reinisch, 2008, Journal of Contemporary History, 43(3), p. 401.

Rationed food was introduced in many countries. In the USSR, the size of the ration depended on the importance of a given group for the country's defense needs: heavy industry workers were entitled to a daily ration of about 4,000 calories a day, while for other industrial workers about 1,000 calories a day. The peasants did not have any rations - it was assumed that they could take care of themselves (Davies, 2008, p. 457). In Great Britain throughout the war, meat was rationed (on average 500g per week for an adult) and from 1943 also fat (200g per week). Let us emphasize that the United Kingdom was a country that experienced "only" air attacks and they were limited in range. However, that still affected the comfort of life of the island's inhabitants. The situation in the areas affected by the army of the Third Reich was incomparably worse.

The scale of the tragedy was the cause of various actions taken by the governments of states participating in the conflict. Initially, they were of an ad hoc nature, with time to assume the form of more organized actions, also at the international level.

\section{Initial proposals of the great powers}

Faced with the drama of war, and the need to rebuild destroyed homes and workplaces, the Allied countries turned to their experience in the First World War. One could call here the American Relief Administration (ARA), led by future US President Herbert Hoover. ${ }^{4}$ The unprecedented nature-also in the depths of devastation - of the Second World War implied the necessity to face the scale of needs and take action on a scale that was previously unknown. Until 1941, the scope of assistance activities was not significant. In August 1941, the Committee of Supplies was established, with Frederick Leith-Ross, the British adviser to Prime Minister, in charge. The task of the Committee was to coordinate assistance activi-

\footnotetext{
${ }^{4}$ ARA, established in February 1919, dealt with food aid for countries affected by war. It operated until June 1922 (after the surrender of Germany, it provided assistance to, among others, Bolshevik Russia), expending for humanitarian purposes about USD 200 million. After the war, a small-scale Interallied Relief Board was also created, in which the United States, the United Kingdom, France and Italy participated (cf. Winid, 1996; Stańczyk, 2007).
} 
ties (prevailing consultations) with the governments of European countries in exile. Created in September of the same year and a continuation of the Supply Committee, the Inter-Allied Committee on European Post-war Relief set equally modest goals for itself. According to J. Łaptos, the Committee, again headed by Leith-Ross, had to "[...] recognize the situation and draw up appropriate plans for the future and, above all, set priorities" (Łaptos, 2001).

The committee with a small bureaucratic apparatus was created as a result of the meeting of Foreign and Finance Ministers, which organized the Foreign Office to support the demands of the Atlantic Charter and the adoption of the principles of post-war supply of Europe. The United States attended a meeting at London's James Palace as an observer and responded favorably to the general provisions adopted.

In January 1942, the Soviet Union proposed that Moscow and London, together with other willing states (but without the United States as a member state), would create a new international organization, on the basis of the Inter-Ally Committee, whose task would be to assess the most important needs of countries and collect information on the resources of food and raw materials. In a memorandum sent on 13 January 1942 to British Foreign Secretary Anthony Eden, the Soviet ambassador to the United Kingdom, Ivan Maisky, clarified that it would also aim for a technical assessment and redistribution of collected materials for needy countries. Decisions in the organization were to be made by consensus (Foreign Relations of the United States Diplomatic Papers [hereinafter: FRUS], 1942, Vol. 1, p. 89). A four or five-person secretariat would consist of a representative of the USSR, Great Britain and two or three representatives elected from other countries. In addition, it was proposed to create two permanent committees: on food and raw materials and on transport. Characteristically, the Soviet proposal saw the United States only in the context of the source of food and raw materials, and not the decision maker in the proposed committee. The Russian project did not receive a friendly reception from the Western Allies, although in the future the suggestions contained therein were used. ${ }^{5}$

The Soviet initiative made the activities of Washington and London more dynamic as part of international assistance. In February 1942, the British proposed their project for a new organization. Presented three months later, the American proposal (a telegram from Secretary of State Cordell Hull to the US ambassador in Great Britain of 7 May 1942 and a memorandum of May 11) corresponded with the British concept. ${ }^{6}$

\footnotetext{
${ }^{5}$ Accurate remarks of Winant, the American ambassador in the United Kingdom, showing the shortcomings of the Soviet proposal are presented in FRUS, Vol. 1, 1942, pp. 91-92.

${ }^{6}$ It provided for the creation of the United Nations Relief Council, in which signatories of the United Nations Declaration of 1 January, 1942 could participate. The Council would have an Executive Committee composed of representatives of the USA, Great Britain, the USSR and China and, after agreement, possible representatives of other countries. The Committee would be chaired by an American. The draft did not exclude the possibility of advisory committees (also created ad hoc) and provided for the transformation of the existing Inter-Allied Committee on Post-war Requirements into an Advisory Committee on European Relief. In addition to the Executive Committee, the Americans also proposed the creation of a United Nations Relief Bureau, headed by the Director-General. The office would be responsible for the current activities of the Board, while the Executive Committee
} 
The British, with little comment ${ }^{7}$, adopted the US project as a basis for further discussion and quickly responded to the invitation to detailed talks in Washington. They took place in June 1942. They were attended by Leith-Ross and financial advisor to the British government John Maynard Keynes. The Americans and the British informed the USSR and China of the meeting, stressing that no binding decisions had been taken. Nevertheless, the meeting should be considered important because on July 10, Undersecretary of State, Dean Acheson, presented to the US Secretary of State, Cordell Hull, the first project of an international aid organization called the Relief and Rehabilitation Administration, which was forwarded to the United Kingdom, USSR ${ }^{8}$ and China. ${ }^{9}$

Acheson's memorandum to Hull on July 11, which was, in fact, a commentary on the proposed concept of the organization, contained an interesting list of priorities on which the US side was interested in the course of further negotiations (FRUS, Vol. 1, 1942, pp. 118-120). The organization's task was to bring help until the state gained economic independence. Therefore, the organization's goal was not to rebuild areas affected by war damage in the long term. As a consequence, the word "rehabilitation" was emphasized as being semantically different from "reconstruction". The assistance carried out in the framework of inter-state cooperation was not intended to be the nucleus of the dependence of countries in need of assistance. The superior political body of the organization was to act on the basis of equality of votes and consensus in making decisions. Representatives had to meet twice a year. Of no less importance was the issue of hierarchy in the organization, which Acheson addressed. In his opinion, as far as possible, it should have a not very centralized structure, with region-based activities. The position of the Political Committee - the body exercising political supervision over the activities of the organization - was also crucial, assuming the participation of the US, Great Britain, USSR and China.

would be the body that would supervise and coordinate the Bureau's actions (FRUS, Vol. 1, 1942, pp. 104-105).

${ }_{7}^{7}$ The comments concerned the location of some of the administrative units - the British insisted on placing them in London. They also raised the question of the competence of the Inter-Allied Committee - for their maximization. Canada, as a British dominion and a significant supplier of food and raw materials, declared its willingness to participate in the organization under special, although initially unspecified conditions. On 27 November, 1942, the United Kingdom proposed extending the Committee to three countries with the mandatory participation of Canada (FRUS, Vol. 1, 1942, p. 150).

${ }^{8}$ On August 13, 1942, Acheson introduced a modified version of the project. The American proposal met with great interest from the USSR. On August 20, Ambassador of the state, during a meeting with Undersecretary of State Adolf Berle, clarified matters concerning, among others, the seat of the organization, the office of the Director General, his right to participate in the Committee's votes, and the number of Deputy Directors.

${ }^{9}$ China's comments were passed on to the Americans in November 1942. They concerned the competences of the Director General towards their weakening to the Political Committee and the procedure for making amendments to the statutes of the organization (resignation from unanimity in the Committee and a qualified majority of $2 / 3$ in the Council in favor of the ordinary majority in both bodies). 


\section{Negotiations among "The Big Four"}

The unfavorable development of the situation on the front (the downfall of Tobruk, the progress of the Third Reich in Eastern Europe, the predominance of Japan over China in the Far East) caused a slowdown in the implemented projects. Study work continued, but information about the new aid initiative was not made public. The electoral calendar in the USA probably also influenced this. In November 1942, elections to Congress took place - the Democrats refused to give isolationists further arguments and risk losing some of the votes (Łaptos, 2001, p. 161). After the improvement of the situation on the African front and the end of the American parliamentary elections, the matter of the new international organization once again gained momentum. On November 21, the White House issued a statement announcing the creation of Foreign Relief and Rehabilitation Operations (FRRO). From December, the position of the head of the newly created cell was to be taken by the former Governor of New York, Herbert H. Lehman. ${ }^{10}$ His task - in accordance with the message - was to administer US activities as part of the United Nations assistance campaign.

The creation of a new structure was delayed due to disagreement over the shape of its statute. The USSR reported the most reservations. In a memorandum forwarded to Hull on December 29, 1942 (FRUS, Vol. 1, 1942, pp. 159-160), Moscow proposed that, each time, the receipt of assistance would require consent given by a state harmed by the actions of the Axis countries. The Russians referred to the practice of the Hoover mission, not authorized by the authorities, after the end of the First World War. It should be added that this was due to the specific political situation in Russia at that time. The Americans protested against the Russian provision because it would make it impossible to provide humanitarian aid to the citizens of an enemy state. Moreover, in many cases, problems could arise in defining the government in a given country. In addition, the Russians expected the Director-General to report regularly on its activities, which would be approved or rejected by the unanimously functioning Political Committee. The USSR also opposed the British proposal to expand the Committee's composition (to include Canada), justifying the difficulty in selecting additional (apart from "The Big Four") countries and making it difficult to obtain the unanimity required to take binding decisions.

The observations of the four superpowers regarding the shape of the organization were the subject of meetings between the ambassadors of the USSR, Great Britain and China with Hull and Acheson, which took place between January and March 1943 (FRUS, Vol. 1, 1942, pp. 853-857). Moscow upheld the opposition to expanding the Committee, in which it gained US support. China took a neutral stance in this matter, highlighting the need to apply the unanimity rule when making decisions within the Committee. The status of Canada as a leading aid provider was to be emphasized by its likely participation in the Supply Committee,

\footnotetext{
${ }^{10}$ He was in the governor's office from 1933. In the same year, F.D. Roosevelt took over the office of US President. The most complete biography of Lehman was presented by Nevins (1963).
} 
which would bring together top donors within the organization. However, British resistance in this matter was significant. The British Ambassador to the United States, Edward Halifax, pointed out that the exclusive structure of the Committee could be the cause of the failure of the future Allied Conference regarding the creation of a new organization. Especially since France, Norway or the Netherlands, for example, would play a significant role in transport and supply within the organization (Halifax to Acheson, 1943, January 24, FRUS, Vol. 1, p. 863).

On the other hand, there was a preliminary agreement on the issue of obtaining state consent for humanitarian aid and the rules for managing its assistance in individual countries. The USSR obtained from Acheson the assurance that within its territory the Kremlin would be responsible for the allocation of resources from the assistance campaign and would decide on their use. Similar assurances were obtained by the Chinese, who also previously made reservations in this respect. During subsequent meetings, the need to obtain the consent of the beneficiary state, understood as the consent of the government exercising power in that country and being a member of the organization, was accepted as suggested by Moscow. There was no agreement on the degree of freedom of the Director General, which would be expressed, among others, in the need to submit periodic reports and ways to cancel it. The Soviet side did not insist to the American proposal that the Committee could dismiss the Director by applying the unanimity rule, noting that it would be very difficult to carry out (unless the US abstained from voting). Therefore, Moscow pushed for the idea of the Director's short term and the principle of unanimity whenever he was elected. Nevertheless, the modified version of the project included an American record on the Director's dismissal by the Committee, while maintaining the principle of consensus. A Chinese proposal was dropped at this stage to simplify the rules for approving amendments to the statutes of the organization. The name of the Political Committee was changed to the Central Committee.

\section{UNRRA and other allied countries. Making the project public}

The above-mentioned modifications resulted in a new version of the draft international agreement creating an assistance organization on March 24, 1943 (cf. FRUS, Vol. 1, 1942, pp. 890-895). It introduced new regional bodies within the organization: Committee of the Council for the Far East and Committee of the Council for Europe. The subject of further negotiations was the cast of directors of these offices, as well as the election of deputies of the General Director. However, key discrepancies between the four powers had already been clarified. It was not until June 9, 1943, that the previously confidential statute of the organization was transferred to the remaining Allied countries and made public in the press (Secretary of State to Some Diplomatic Representatives, FRUS, Vol. 1, 1943, June 9, pp. 909-910). The document was criticized mainly in the part concerning the main authorities. The exclusivity of the cast of the Central Committee, as well as the 
rules for convening an extraordinary session of the Council, were contested (the project assumed that apart from two annual sessions, the Council would meet at the request of the majority of members). Proposals were made that one-third or a quarter of all Member States should apply (Memorandum of Roy Veatch, an official from the Office of Foreign Assistance and US Assistance Operations, FRUS, 1943, July 16, Vol. 1, pp. 914-915). In a telegram to Hull, Winant informed him about the "cool" acceptance of the project by Belgium, the Netherlands and Norway and the "tepid" reception by Poland" and Yugoslavia (Winant to Hull, FRUS, Vol. 1, 1943, 5 July, p. 929-931). At the same time, the subdued reaction of the last two countries resulted not so much from the smaller scale of objections to the provisions of the document as from the urgent need to obtain assistance. From the recognition of the moods and reactions that Winant gauged, it appeared that the Netherlands questioned China's participation in the Committee, arguing that it is not a power in the economic sense and would not be able to meet the financial needs of reconstruction. The Norwegians reported their accession to the Committee. The Belgians also felt unreasonable, raising the military contribution of Congo to the course of the war on the front.

11 The government-in-exile worried that the UNRRA statute consolidated the principle of the directorate of the four powers in shaping the war and post-war order-this was expressed by the composition of the Committee. The threat posed by the USSR's involvement in international cooperation, and the possible consequences which would probably be harmful to Poland, was also pointed out (in April 1943, Moscow broke off diplomatic relations with the London government). In addition, Poland raised the issue of the possible use of food as a political weapon. Polish Ambassador to the US, Jan Ciechanowski, raised this issue in an interview with Acheson in July 1943, citing the use of such wording in Sikorski's conversations with Roosevelt and later with Lehman. In both conversations, Ciechanowski was a translator. Acheson informed Hull about these remarks, and he introduced the situation to Roosevelt. The US President in a memorandum of July 10 informed Hull that in an interview with Sikorski he spoke about food as a weapon in the current war, stressing that after its end it should be passed first to the coalition of the United Nations and then to the Germans (FRUS, Vol. 1, 1943, pp. 922-923; see also: Brzeziński, 1998, pp. 93-94). The official response of the Polish government to emigration took place on July 24 in the note of Minister of Foreign Affairs Tadeusz Romer to Biddle, the American ambassador to the London government. The Polish government expressed interest in the project, complimenting the principle of allocating aid in the first place to countries that are the earliest victims of the occupation. At the same time, it was proposed that the estimates and distribution of assistance be organized on the basis of "national plans" that would best and accurately reflect the scale of the needs of the affected states. These plans would be coordinated by regional committees, which would also have to approve these plans. The adoption of this proposal would lead to the necessity of introducing changes to the points concerning the entities administering the aid, to increase the competences of the regional committees and to reduce these competences of the Deputy Directors General. The government also advocated extending the Committee to two of the nine European countries that were members of the United Nations. At the same time, membership of this group of nine countries would have a rotational nature. The work on the Committee should be on an equal footing (including the right to vote) with the countries whose issues were being discussed. It was underlined that the Committee's task should be to fulfill the tasks indicated by the Council. This should not be an autonomous policy. Limiting the importance of the Committee would also be the result of the Council's proposed principle of exclusive competence of the Council when deciding on the admission of new Member States, appointing committee members, amending the statute, dismissing the Director General. Romer to Biddle, July 24, 1943 (FRUS, Vol. 1, 1943, pp. 954-957). 
On July 21, 1943, a meeting of representatives of the four powers took place, during which the issue of the Allies' reaction to the proposed relief action, among others, was raised. Acheson informed the interlocutors that outside of the Netherlands - whose opposition sounded the most firmly - the allied countries, despite their remarks, responded positively to the proposed assistance action (FRUS, Vol. 1, 1943, pp. 943-947). Most of the states that responded to the June notes with a proposal for a contract raised the issue of the composition and scope of the Committee's activities. In this situation, three variants of the further conduct of the four powers were possible: insisting on the formula developed so far, a change of the composition of the Committee by expanding its composition, or modifying the scope of competence of this Committee. It was assumed that the last solution would be the best.

The possible changes went towards modifying the provisions regarding the majority required to convene an extraordinary meeting of the Council (introducing the majority of one third of the members instead of the usual majority); give voting rights to states participating in the Council meeting (except the USA, the USSR, Great Britain and China) when matters of vital interest are discussed; deletion of the clause on the competence of the Committee regarding the admission of new members to the organization (outside the Council sessions); the rules for selecting members of the Supply Committee and regional committees; the mode of adopting amendments. The fifth and sixth articles on supply were the subject of controversy. Washington suggested that the modified provision should emphasize that the interested governments/authorities of the country decide which resources should be transferred as part of the assistance campaign. This objection stemmed from the protests of some US senators who were afraid that, otherwise, all US resources would have to be a "reserve" for the UNRRA. The United States also raised the question of the withdrawal from UNRRA, proposing to add an appropriate article. It was clear that the signing of the agreement planned for September 1943 would be delayed.

\section{The statutory foundations of UNRRA}

These proposals were the subject of further discussions and resulted in another modification of the agreement establishing UNRRA, sent by the US to the other three powers (FRUS, Vol. 1, 1943, pp. 978-984, 988). As the latter did not bring any serious reservations on September 20, the final version of the text was adopted. Three days later it was sent to the other coalition governments and published the next day in the press (Beavans, 1969, pp. 845-863).

According to the agreement, the task of the UNRRA Member States was to help, understood as providing food, medicines, clothes or shelter. The area of interest was also the subject of the return of displaced persons during the war. The last mentioned goal was to help damaged countries in the resumption of agricultural and industrial production. Assistance activities of the administration in 
a given state had to be preceded by receiving the consent of the government (or, more broadly, the authorities) of that state to receive aid. In the final version, there was a modified entry regarding the procedure for accepting new members. According to this amendment, as a rule, the Council decided to expand the Administration. During the breaks between sessions, the Council could authorize the Committee to decide on accepting or rejecting membership requests.

The ordinary sessions of the Council, which was nominally the main body of the Administration, were to be held at least twice a year. The Council met at extraordinary meetings at the request of the Committee or one-third of its members. The Central Committee, consisting of representatives of the US, USSR, Great Britain and China, was to be a permanent body organizing the activities of the Administration outside of the sessions of the Council. According to the suggestions of some states not represented in the Committee, the agreement included a provision that the Committee should make political decisions only in emergencies and they could be subject to verification by the Council. Other states could participate in the Central Committee meetings, as long as the subject matter of the meeting concerned their interests. Contrary to the expectations of smaller countries, the proposal to grant them the right to vote in this situation was omitted.

In addition to the Council and the Central Committee, a Supply Committee was established, which included countries that were the main suppliers of materials. Its members were to be appointed by the Council or, with its authorization, by the Central Committee. Members of two regional committees were appointed on similar principles, for Europe (it replaced the Inter-Allied Committee on European Post-war Relief) and the Far East. The task of these Committees was to present proposals to the Council and the Central Committee as part of specific activities in the relevant areas.

UNRRA was headed by the General Director appointed by the Council, with the unanimity of the members of the Central Committee. The Director could be removed from office on the same basis. His competencies included appointing his deputies, administration, and experts, including field missions. He was obliged to submit periodic reports on his activities to the Council and the Central Committee. These reports had to be made public. On the one hand, it was the Council and the Central Committee that were designated as the most important decision-making bodies of the Administration, but on the other hand, the Director was in charge when deciding and carrying out aid operations. The subsequent agreement on the establishment of UNRRA was the result of a compromise that had to reconcile the conflicting interests of the great powers. The contract specified the issue of delivering materials later allocated for assistance. At Washington's request, a provision was made that it was the governments of each state who would decide which resources contribute to the pool provided for helping others. The General Manager also had to take care of the quantity and condition of using the materials.

The disputed way of amending the contract was resolved by introducing three modes of contract amendment. Amendments that would impose new obligations on Member States required a two-thirds majority of Council votes and the consent of that country to accept new commitments. Changes concerning the Administra- 
tion bodies (Council, Director, Committees) would enter into force after their adoption by a two-thirds majority in the Council, with the unanimity of the members of the Central Committee. The majority of two-thirds of votes in the Council would suffice to accept the remaining amendments. The contract specified the rules for leaving the Administration. A State was able to withdraw from participation in UNRRA not earlier than six months after the entry into force of the contract for that State, with a twelve-month notice period (Beavans, 1969).

\section{Conclusions}

The agreement establishing UNRRA was signed on November 9, 1943, in the East Room of the White House in the presence of President Roosevelt. ${ }^{12}$ The signatories were 44 countries. A day later, in Atlantic City (New Jersey), the inaugural meeting of the Council took place (lasting until December 1), chaired by Acheson. Lehman was elected the Director-General. Leith-Ross became his deputy and chairman of the Council of Europe Committee. The conference ran without major misunderstandings, which augured well for cooperation in the coming months. ${ }^{13}$ The connection between the divergent interests of the countries was the size of the necessary aid: to provide 9.2 million tonnes of food, 41.2 million tonnes of coal and other raw materials ("Plan of Campaign," 1943).

Some might consider that the creation of UNRRA took place too late. From the establishment of the Leith-Ross Committee, which was the beginning of the administration until its final creation, twenty-seven months passed. It is also necessary to take into account the additional time from when the first deliveries were launched in 1944. All this may give the impression that the activities around UNRRA were fought sluggishly and thousands of people in need could have been helped at that time. The following circumstances must be taken into account, which explains the delay in starting the program: first of all, the scale of challenges and the number of countries participating in the Administration. Although the most important significance for the final shape of the agreement was the doubts raised by the four powers, the adoption of the text of the agreement by 44 countries required a compromise formula-which always means timeconsuming negotiations. In addition, UNRRA was a program that burdened the budgets of countries providing resources during the war. This meant both the use of a pool of resources that could be passed on to immediate needs in the countries as well as the need to convince the public to use funds to save other countries. ${ }^{14}$

\footnotetext{
${ }^{12}$ In his speech, Roosevelt stressed that UNRRA should be a practical implementation of the Charter's postulate-freedom from want (Address of the President in Connection with the Signing of the Agreement Setting up the United Nations' Relief and Rehabilitation Administration, a copy of the document is available on the website https://www.cvce.eu)

${ }^{13}$ The Indian delegation, in the face of the famine prevailing in the country, unsuccessfully requested assistance under UNRRA. The refusal was argued on the grounds that India was not occupied by enemy troops ("Drama in Atlantic City," 1943).

${ }^{14}$ The total aid value exceeded USD 2.9 billion, of which China received the most $-\$ 529.7$ million, Poland-\$481 million and Italy-\$420.7 million. The largest contribution to UNRRA was made by the
} 
The war situation was no less important. Since the aid was to be intended for countries liberated from occupation, it was undisputed that the first deliveries could take place only after the enemy withdrew and the government took power. The latter condition was often the source of controversy and the subject of political play - in the case of Poland, fatal in consequence.

\section{References}

Beavans, Ch. (Ed.). (1969). Treaties and other international agreements of the United States of America (1776-1949), 1931-1945 (Vol. III). Washington: Multilateral.

Brzeziński, A. M. (1998). Z polityki rządu RP na uchodźstwie wobec UNRRA (19431945). Przeglad Zachodni, 2, 89-113.

Davies, N. (2008). Europa walczy 1939-1945. Nie takie proste zwycięstwo (E. Tabakowska, Trans.). Kraków: Znak.

Drama in Atlantic City. (1943, December 6). Time.

Foreign Relations of the United States Diplomatic Papers. (1942).

Foreign Relations of the United States Diplomatic Papers. (1943).

Jachowicz, P. (1998). Działalność UNRRA w Polsce. Zeszyty Naukowe Wyższej Szkoły Informatyki $i$ Zarzadzania $w$ Rzeszowie, 2, 41-55.

Kaliński, J. (2004). Historia gospodarcza XIX i XX w. Warsaw: Polskie Wydawnictwo Ekonomiczne.

Łaptos, J. (2001). Stanowisko rządu PR na uchodźstwie wobec UNRRA w latach 19431945. Prace Komisji Środkowoeuropejskiej, 9, 157-178.

Nevins, A. (1963). Herbert Lehman and his era. New York: Charles Scribners Sons.

Plan of Campaign. (1943, 22 November). Time.

Reinisch, J. (2008). Introduction: Relief in the aftermath of war. Journal of Contemporary History, 43(3), 371-404.

Rozbick, M. J., \& Michałek K. (Eds.). (1994). A selection of sources on the history and culture of the United States of America. From colonization to 1945. Warsaw: Wydawnictwa Uniwersytetu Warszawskiego.

Stańczyk, Z. L. (2007, September 14). Herbert Hoover a Polska. Przeglad Polski.

Tarka, K. (2003). Wspomnienia M. Sokołowskiego z pracy w UNRRA w latach 1943-45. Zeszyty Historyczne, 145, 169-185.

Winid, B. (1996). After the Colby Note: The Wilson administration and the PolishBolshevik war. Presidential Studies Quarterly, 26(4), 1165-1169.

US - \$2.7 billion, the United Kingdom-\$62.7 million and Canada \$138.7 million (Tarka, 2003, pp. 169-185; on the subject of UNRRA assistance for Poland compared to other countries, see also: Jachowicz, 1998, pp. 41-55). 